\title{
POLA PENYEBARAN SPASIAL INVESTASI DI INDONESIA: SEBUAH PELAJARAN DARI MASA LALU
}

\author{
J. J. Sarungu \\ Fakultas Ekonomi Universitas Sebelas Maret Surakarta, Jawa Tengah \\ E-mail: jsarungu@yahoo.co.id
}

\begin{abstract}
Economic development theorists generally beliefs that investment mainly played an important role in economic growth. Based on that, one can easily to think that spatially disparity of economic growth mostly depends on spatially spread of investment. This work try to investigate the spatially spread pattern of investment in Indonesia in the past before the Asian financial and economic crisis occurred. In that time, the government development policy stressed not only on economic growth but also on reducing economic disparity included spatially. In the recent, the two kinds of economic development policies' stressing are still continued by the government. Generally, the lessons from the past is that the spatially spread pattern of investment in Indonesia tended to still concentrated in the western Java island (in Jakarta and its surrounding) and also in the Sulawesi island. While in the other island, investment tended to spread.
\end{abstract}

Key words: spatially spread pattern, investment, economic disparity

\section{PENDAHULUAN}

Dalam berbagai literatur ilmu ekonomi pembangunan, secara umum ditegaskan bahwa terdapat tiga sumber utama pertumbuhan ekonomi suatu masyarakat atau bangsa, yaitu: (i) akumulasi modal, baik fisik, finansial maupun sumber daya manusia; pertumbuhan penduduk dan angkatan kerja, dan (iii) perkembangan teknologi (Todaro, 1977:71). Secara teoritik-historik, akumulasi kapital atau investasi dinyatakan sebagai faktor utama pendorong pertumbuhan ekonomi. Hal ini ditegaskan sejak dari teoriteori ekonomi pembangunan Neoklasik hingga teori-teori ekonomi pembangunan kontemporer. Secara empirik, telah diungkapkan pula bahwa akumulasi kapital atau investasi berpangaruh positif dan siknifikan terhadap pertumbuhan ekonomi.

Secara regional, kenyataan telah menunjukkan pula bahwa terdapat perbedaan pertumbuhan ekonomi yang signifikan antara region/wilayah baik secara internasional maupun secara nasional. Perbedaan pertumbuhan ekonomi antar region/wilayah tersebut adalah hal yang wajar sebagai akibat perbedaan akumulasi kapital atau investasi diberbagai region/wilayah pula.

Faktor utama lainnya adalah kondisi objektif potensi ekonomi dan kebijakan pembangunan yang ditempuh di masingmasing negara dan wilayah. Faktor ini juga sangat menentukan karena merupakan "manmade", bahkan disparitas akumulasi kapital atau investasi antarregion/wilayah dapat 
terjadi sebagai akibatnya. Beberapa hasil studi telah menunjukkan bahwa pada region/wilayah yang daya serap investasinya tinggi, perekonomiannya cenderung bertumbuh relatif pesat dibanding dengan yang sebaliknya. Di Indonesia, Forbey and Thrift (1987:67) telah mengungkap bahwa: "most foreign and domestic investment in Indonesia has been in West Java, principally in and around Jakarta".

Dari perspektif pembangunan regional/ wilayah dalam kaitannya dengan disparitas pertumbuhan ekonomi antarregion/ wilayah maka aspek penyebaran (spread) akumulasi kapital atau investasi secara regional menjadi masalah yang yang menarik untuk dikaji. Jika investasi dipandang sebagai "mesin" kegiatan ekonomi masyarakat maka penyebaran kegiatan ekonomi secara regional akan cenderung mengikuti salah satu dari dua pola penyebaran empirik. Pola pertama menunjukkan bahwa pada tahap awal industrialisasi, kegiatan ekonomi masyarakat akan terkonsentrasi di pusat wilayah nasional, biasanya di satu area Metropolitan. Kemudian setelah tahap industrialisasi mencapai tahap "maturity" maka polarisasi akan mulai terjadi di mana pusat-pusat wilayah sekunder (secondary core region) mulai bermunculan di daerah pinggiran (in the hinterlands). Pola ini sering disebut "the Core-Periphery Model atau "Theory of Polarized Growth (Friedman, 1966). Model ini menegaskan bahwa efek "trickle-down effect" akan terjadi.

Pola kedua menyatakan bahwa pada tahap awal industrialisasi, kegiatan ekonomi masyarakat akan terkonsentrasi pada suatu pusat region/wilayah nasional dan pada tahap berikutnya kegiatan ekonomi justru semakin terkonsentrasi di pusat wilayah tersebut. Jadi sekali terkonsentrasi maka seterusnya akan semakin terkonsentrasi di suatu pusat region. Pola ini sering disebut "The Circular and Cummulative Causation Model (Gunnar Myrdal, 1968). Model ini berkebalikan dengan model sebelumnya, yang justru lebih menegaskan bahwa "effect trickle-up" yang akan terjadi.

Tulisan ini menyajikan pola penyebaran investasi di Indonesia secara regional selama periode 1985-1995 atau periode sebelum krisis keuangan dan ekonomi tahun 1997. Penetapan periode pengamatan tersebut didasarkan pada pertimbangan sebagai berikut: (i) periode tersebut merupakan periode sebelum krisis ekonomi dan keuangan yang hebat, (ii) periode tersebut merupakan bagian dari periode pembangunan dimana upaya pemerataan pembangunan antarregion/wilayah merupakan salah satu strategi pembangunan. Dengan demikian akan dapat dipelajari apakah hasil pembangunan telah sesuai dengan strategi pembangunan yang telah ditetapkan sebelumnya. Atau seperti papatah: "pengalaman adalah guru yang terbaik" !

\section{METODE PENELITIAN}

\section{Batasan Investasi}

Investasi dalam kajian ini merujuk pada pengertian investasi tetap domestik regional bruto, yang oleh BPS diberi batasan sebagai berikut:

"Pembentukan modal tetap domestik regional bruto meliputi berbagai macam pengeluaran barang modal baru yang dihasilkan di domestik/ region dan barang modal baru maupun bekas yang berasal dari domestik/ region lain atau impor (luar negeri). Barang modal yang dibeli atau dibuat sendiri adalah peralatan yang digunakan untuk 
berproduksi dan biasanya mempunyai umur pemakaian satu atau lebih. Termasuk pengeluaran untuk pembentukan modal tetap bruto adalah pengeluaran untuk meningkatkan mutu dan perbaikan berat yang nilainya relatif besar. Perbaikan berat dimasukkan sebab bertujuan menambah umur dan kapasitas produksi dari barang modal” (BPS, 1988:9).

\section{Data dan Sumbernya}

Data investasi tetap domestik regional bruto diperoleh BPS melalui sensus ekonomi dan survai sosial ekonomi nasional (SUSENAS) dengan menggunakan metode tidak langsung (indirect method), yaitu pendekatan arus barang (commodity flow approach). Dalam pendekatan tersebut, penghitungan didasarkan pada penyediaan bahan-bahan atau barang-barang yang digunakan untuk pembentukan modal tetap yang diperoleh dari statistik impor, statistik perdagangan antarpulau dan statistik produksi sektor-sektor yang produksinya digunakan sebagai bahan pembentukan modal (BPS, 1988:9). Jadi dalam hal ini, data tersebut dipandang sebagai data realisasi dan karena itu telah membawa efek ekonomi pada berbagai macam kegiatan masyarakat secara umum.

Data investasi tetap domestik regional bruto dihitung menurut propinsi dan tahun berdasarkan baik harga berlaku (current price) maupun pada harga konstan (constant price) tahun 1983 dan 1993. Data investasi yang digunakan dalam kajian ini adalah data investasi pada harga konstan 1983 yang telah dipublikasi oleh BPS dalam "Pendapatan Regional Propinsi-propinsi di Indonesia Menurut Penggunaannya", periode tahun
1983-1988; tahun 1983-1989; dan tahun 1993-1995.

\section{Konsep, Prosedur, dan Teknik Analisis}

Konsep, prosedur, dan teknik analisis yang digunakan dalam kajian ini adalah:

1. Investasi dalam hal ini didasarkan pada besarnya kontribusi (share) propinsi atau wilayah (region) terhadap nasional dan perubahannya selama periode tahun 1985-1995.

2. Untuk mengungkap dan memahami bagaimana penyebaran investasi menurut propinsi dan wilayah serta perkembangannya di Indonesia, digunakan teknik analisis Koefisien Entropy Theil (Theil Entropy Coefficient/T) dan Koefisien Deviasi Logaritmik Rata-rata (The Mean Logaritmic Deviation Coefficient/ L) (Poot, Kuyvenhoven and Jansen, 1990:181). Koefisien T dan L masingmasing dihitung dengan formula sebagai berikut:

$$
\begin{aligned}
& T=\frac{1}{n U^{*}} \sum^{n} \overline{Y_{i}} \ln \left(\frac{Y_{i}}{U^{*}}\right) \\
& L=\frac{1}{n} \sum^{n} \ln \left(\frac{U^{*}}{Y_{i}}\right)
\end{aligned}
$$

yang mana,

- Yi adalah investasi perkapita propinsi atau wilayah ke i ( $\mathrm{i}=1,2,3$, ......, n);

- $\mathrm{n}$ adalah jumlah propinsi atau wilayah pengamatan;

- $\mathrm{U}^{*}$ adalah rata-rata investasi perkapita menurut propinsi atau wilayah;

- Ln adalah logaritma normal. 
- Besarnya koefisien T dan L bergerak dari nilai 0 ke nilai positif $(+)$.

Semakin besar nilainya, semakin timpang penyebaran investasi menurut propinsi atau wilayah. Hal ini mengindikasikan bahwa pola penyebarannya semakin terpusat (concentrated) di propinsi atau wilayah tertentu. Sebaliknya, jika nilainya semakin mendekati 0 maka pola penyebarannya cenderung semakin tersebar (spread).

Kedua teknik analisis tersebut di atas digunakan secara bersamaan dengan maksud perbandingan dan pengecekan silang (cross check) di antara keduanya. Hal ini diperlukan karena pada hakekatnya secara konseptual teoritik keduanya memiliki sifat yang berbeda meskipun mempunyai fungsi yang sama. Koefisien $\mathrm{T}$ lebih sensitif terhadap nilai-nilai yang tinggi dalam dalam suatu distribusi; sedang koefisien L sebaliknya lebih sensitif terhadap nilai-nilai yang rendah (Poot, Kuyvenhoven and Jansenm 1990:146).

3. Penghitungan koefisien $\mathrm{T}$ dan $\mathrm{L}$ dilakukan dalam tiga kategori wilayah, yaitu:

1). Kategori antarpropinsi di Indonesia. Propinsi dalam hal ini adalah propinsi sebelum adanya pemekaran era reformasi, 2). Kategori antarpropinsi dalam wilayah di Indonesia, dan 3). Kategori antarwilayah di Indonesia.

Ketiga kategori tersebut di atas dihitung pada tiga titik waktu (tahun), yaitu masing-masing tahun 1985, 1990, dan 1995. Wilayah dalam hal ini diklasifikasi ke dalam tiga kelompok, yaitu: (i) Wilayah menurut pulau besar dan kepulauan di Indonesia yang terdiri atas lima wilayah: Sumatera, Jawa, Kalimantan, Sulawesi, dan Bagian Indonesia lainnya yang mencakup: Bali, NTB, NTT, Maluku dan Papua); (ii) Wilayah menurut kawasan pembangunan yang terdiri atas: Kawasan barat Indonesia (KBI) meliputi semua propinsi di Sumatera, Jawa (13 propinsi), dan Kawasan Timur Indonesia (KTI) mencakup semua propinsi di luar pulau Sumatera dan Jawa. (13 propinsi); (iii) Wilayah menurut pemilikan sumber daya alam enerji-mineral (SDA-EM) yang terdiri atas dua wilayah, yaitu: Wilayah dengan SDA-EM meliputi propinsi-propinsi Nangroe Aceh Darussalam (Daerah Istimewa Aceh), Sumatera Utara, Sumatera Barat, Riau, Sumatera Selatan, Jawa Barat, Jawa Timur, Kalimantan Timur, Sulawesi Selatan, Sulawesi Utara, Maluku, dan Papua, dan Wilayah tanpa SDA-EM meliputi propinsi-propinsi selain yang telah disebut di atas. Yang termasuk SDA-EM dalam hal ini adalah minyak (oil), gas alam (natural gas), batubara (cool), bauksit (bauxite), nikel (nickel), tembaga (cooper) dan timah (tin).

\section{HASIL DAN PEMBAHASAN}

\section{Struktur dan Perkembangan Investasi Menurut Wilayah, Tahun 1985-1995}

Struktur dan perkembangan investasi menurut wilayah di Indonesia periode tahun 19851995 dapat dilihat pada Tabel 1. Pada tabel tersebut, tampak bahwa pada tahun 1985 andil (share) propinsi dalam hal investasi berada pada rentang besaran antara yang terendah sebesar 0,28 persen (propinsi Nusa Tenggara Timur) dan yang tertinggi sebesar 
20,77 persen (DKI Jakarta). Pada tahun 1990 andil propinsi dalam hal investasi berada pada rentang besaran antara yang terendah sebesar 0,35 persen (propinsi Sulawesi Utara dan Jambi) dan yang tertinggi sebesar 21,54 persen (DKI Jakarta). Sedang pada tahun 1995 andil propinsi dalam hal investasi berada pada rentang besaran antara yang terendah sebesar 0,33 persen (propinsi Sulawesi Utara) dan yang tertinggi sebesar 26,27 persen (DKI Jakarta). Jadi, tampak bahwa andil propinsi yang tertinggi dalam hal investasi selama periode pengamatan tetap pada propinsi DKI Jakarta yang mencakup seperempat hingga lebih seperlima dari investasi di Indonesia.

Dari segi perkembangan andil propinsi dalam hal investasi, maka tampak bahwa propinsi DKI Jakarta menunjukkan perkembangan yang paling pesat. Sementara, perkembangan andil propinsi dalam hal

Tabel 1. Investasi Tetap Domestik Regional Bruto Menurut Propinsi di Indonesia, Tahun 1985-1995 (persen)

\begin{tabular}{|c|c|c|c|c|c|c|}
\hline \multirow{2}{*}{ No. } & \multirow{2}{*}{ Propinsi } & \multicolumn{3}{|c|}{ Investasi Tetap Domestik Regional Bruto } & \multicolumn{2}{|c|}{ Pertumbuhan/Thn } \\
\hline & & 1985 & 1990 & 1995 & $85-90$ & $90-95$ \\
\hline 1. & DI Aceh & 0,76 & 1,08 & 1,34 & 4,26 & 38,01 \\
\hline 2. & SUMUT & 6,21 & 5,88 & 5,23 & 6,16 & 30,43 \\
\hline 3. & SUMBAR & 0,92 & 0,71 & 1,58 & 2,04 & 49,71 \\
\hline 4. & Riau & 8,45 & 12,17 & 4,05 & 14,56 & 11,57 \\
\hline 5. & Jambi & 1,13 & 0,35 & 0,89 & $-16,25$ & 52,35 \\
\hline 6. & SUMSEL & 5,81 & 5,44 & 3,68 & 5,91 & 25,78 \\
\hline 7. & Bengkulu & 0,60 & 0,66 & 0,52 & 8,97 & 28,87 \\
\hline 8. & Lampung & 1,14 & 0,78 & 1,98 & $-0,31$ & 52,22 \\
\hline 9. & DKI Jakarta & 20,77 & 21,54 & 26,27 & 7,98 & 37,55 \\
\hline 10. & JABAR & 14,94 & 13,93 & 13,83 & 5,84 & 33,45 \\
\hline 11. & JATENG & 8,97 & 8,74 & 8,24 & 6,74 & 32,41 \\
\hline 12. & DI Jogja & 1,89 & 0,89 & 1,20 & 3,20 & 39,50 \\
\hline 13. & JATIM & 13,44 & 16,00 & 14,16 & 10,74 & 31,13 \\
\hline 14. & KALBAR & 2,25 & 1,06 & 1,64 & $-7,86$ & 42,36 \\
\hline 15. & KALTENG & 0,64 & 0,43 & 0,80 & $-0,84$ & 46,04 \\
\hline 16. & KALSEL & 1,75 & 0,80 & 0,86 & $-8,42$ & 35,10 \\
\hline 17. & KALTIM & 3,72 & 3,07 & 4,83 & 3,39 & 42,66 \\
\hline 18. & SULUT & 0,85 & 0,62 & 0,69 & 0,91 & 35,81 \\
\hline 19. & SULTENG & 0,44 & 0,37 & 0,54 & 3,43 & 41,46 \\
\hline 20. & SULSEL & 1,96 & 1,61 & 1,76 & 3,31 & 35,38 \\
\hline 21. & SULTRA & 0,32 & 0,35 & 0,33 & 9,06 & 32,60 \\
\hline 22. & Bali & 2,13 & 1,40 & 1,57 & $-1,12$ & 35,83 \\
\hline 23. & NTB & 0,63 & 0,89 & 0,81 & 14,38 & 31,50 \\
\hline 24. & NTT & 0,26 & 0,42 & 0,72 & 17,09 & 44,20 \\
\hline 25. & Maluku & 0,48 & 0,47 & 0,62 & 6,78 & 39,00 \\
\hline \multirow[t]{2}{*}{26.} & IRJA & 0,32 & 0,36 & 1,81 & 9,60 & 65,68 \\
\hline & $\begin{array}{l}\text { To t a I } \\
\text { (Rp. Juta) }\end{array}$ & $\begin{array}{c}100,00 \\
(16.033 .445)\end{array}$ & $\begin{array}{c}100,00 \\
(23.044 .391)\end{array}$ & $\begin{array}{c}100,00 \\
(123.514 .614)\end{array}$ & $\begin{array}{c}7,25 \\
-\end{array}$ & $\begin{array}{c}33,58 \\
-\end{array}$ \\
\hline
\end{tabular}

Sumber: Biro Pusat Statistik; Pendapatan Regional Propinsi-propinsi di Indonesia Menurut Penggunaannya, 19831988; 1983-1989; dan 1993-1995 (diolah). 
investasi yang rendah dan lamban ditunjukkan oleh propinsi-propinsi Nusa Tenggara Timur, Sulawesi Utara, dan Jambi. Selisih besaran andil propinsi dalam hal investasi yang tertinggi dan yang terendah semakin melebar. Hal ini menunjukkan kecenderungan struktur investasi menurut wilayah propinsi semakin timpang di mana wilayah yang perkembangan ekonominya pesat akan semakin berkembang pesat, sedang wilayah yang perekonomiannya lambat akan tetap lamban.

Jika struktur dan perkembangan investasi dilihat menurut wilayah Pulau dan kepulauan maka tampak pada Tabel 2 bahwa pada tahun 1985 andil wilayah yang terbesar dalam hal investasi ditunjukkan oleh wilayah pulau Jawa (59,21 persen). Sedang andil wilayah yang terendah ditunjukkan oleh wilayah pulau Sulawesi (3,59 persen). Pada tahun 1990 andil wilayah dalam hal investasi yang terbesar ditunjukkan oleh wilayah pulau Jawa (61,10 persen) sedang yang terkecil ditunjukkan oleh wilayah pulau Sulawesi (2,95 persen). Sedang pada tahun 1995, andil wilayah dalam hal investasi yang terbesar tetap ditunjukkan oleh wilayah pulau Jawa $(63,70$ persen $)$ sedang andil wilayah yang terendah juga tetap ditunjukkan oleh wilayah pulau Sulawesi (3,33 persen). Dari struktur investasi seperti di atas, tampak bahwa lebih dari separuh investasi di Indonesia berada di wilayah pulau Jawa dengan kecenderungan yang semakin meningkat dari sebesar 59,21 persen menjadi 63,70 persen.

Jika struktur dan perkembangan investasi tersebut dilihat menurut wilayah pembangunan kawasan bagian barat Indonesia (KBI) dan wilayah pembangunan kawasan bagian timur Indonesia (KTI) maka tampak pula pada Tabel 2 bahwa lebih dari 80 persen investasi dilakukan di wilayah pembangunan KBI sedang selebihnya dilakukan di wilayah pembangunan KTI. Hal ini menunjukkan pula bahwa struktur investasi menurut wilayah pembangunan kawasan di Indonesia sangat timpang yang lebih fokus ke KBI yang meliputi pulau Jawa dan pulau Sumatera. Tampak pula bahwa dalam kurun waktu pengamatan, ketimpangan struktur investasi seperti tersebut di atas cenderung tidak berubah. Hal ini sebenarnya sangat menarik karena pada akhir tahun 1980-an dan awal tahun 1990-an ketimpangan wilayah di Indonesia sudah mulai disadari oleh berbagai pihak termasuk pemerintah ketika itu. Oleh karena itu, kemudian oleh pemerintah dilakukan reorientasi berbagai kebijakan pembangunan nasional yang lebih beroerientasi ke wilayah pembangunan kawasan timur Indonesia. Tetapi, dalam pengamatan ini ternyata perkembangannya tidak berubah.

Selanjutnya, jika struktur dan perkembangan investasi dilihat menurut wilayah pemilikan sumber daya alam enerji-mineral (SDA-EM) yang meliputi: minyak bumi, gas alam, batu bara, bauksit, nikel, tembaga dan timah maka tampak pula pada Tabel 2 bahwa lebih dari separuh investasi di Indonesia dilakukan di wilayah dengan pemilikan sumber daya alam energi-mineral (dengan SDA-EM) sedang selebihnya dilakukan di wilayah tanpa pemilikan sumber daya alam enerji-mineral (tanpa SDA-EM). Tampak pula bahwa perkembangan struktur tersebut selama periode pengamatan cenderung tidak berubah. 
Tabel 2. Investasi Menurut Wilayah di Indonesia, Tahun 1985-1995 (persen)

\begin{tabular}{|c|c|c|c|c|c|c|}
\hline \multirow{2}{*}{ No. } & \multirow{2}{*}{ Wilayah } & \multicolumn{3}{|c|}{ Investasi } & \multicolumn{2}{|c|}{ Pertumbuhan/Thn } \\
\hline & & 1985 & 1990 & 1995 & $85-90$ & $90-95$ \\
\hline \multirow[t]{6}{*}{1.} & \multicolumn{6}{|c|}{ Pulau dan Kepulauan: } \\
\hline & Sumatera & 25,01 & 27,05 & 19,32 & 26,84 & 26,84 \\
\hline & Jawa & 59,21 & 61,10 & 63,70 & 7,88 & 32,54 \\
\hline & Kalimantan & 8,37 & 5,35 & 8,13 & $-1,63$ & 53,89 \\
\hline & Sulawesi & 3,59 & 2,59 & 3,33 & 3,31 & 38,04 \\
\hline & Indo.lainnya & 3,82 & 3,55 & 5,52 & 5,81 & 42,39 \\
\hline \multirow[t]{3}{*}{2.} & \multicolumn{6}{|c|}{ Kawasan Indonesia: } \\
\hline & $\mathrm{KBI}$ & 84,23 & 88,15 & 83,02 & 8,17 & 32,28 \\
\hline & KTI & 15,77 & 11,85 & 16,98 & 1,54 & 40,77 \\
\hline \multirow[t]{4}{*}{3.} & \multicolumn{6}{|c|}{$\begin{array}{l}\text { Pemilikan SDA-EM: } \\
\text { Dengan }\end{array}$} \\
\hline & SDA-EM & 57,33 & 61,05 & 53,22 & 8,51 & 30,84 \\
\hline & Tanpa & & & & & \\
\hline & SDA-EM & 42,67 & 38,95 & 46,78 & 5,43 & 37,24 \\
\hline 4. & Indonesia & 100,00 & 100,00 & 100,00 & 7,25 & 33,58 \\
\hline
\end{tabular}

Sumber: Tabel 1 (diolah)

\section{Pola Penyebaran Investasi Menurut Wilayah, Tahun 1985-1995}

Hasil pengolahan data berdasarkan analisis Koefisien Entropi Theil (T) dan Koefisien Deviasi logaritmik Rata-rata (L) dapat dilihat pada Tabel 3. Pola penyebaran investasi perkapita dalam tabel tersebut diklasifikasi ke dalam tiga kategori yaitu: a. Antarpropinsi di Indonesia, b. Antarpropinsi dalam wilayah di Indonesia, yang meliputi: wilayah pulau dan kepulauan, wilayah kawasan barat dan timur Indonesia, dan wilayah dengan dan tanpa pemilikan sumber daya alam-energi mineral (SDA-EM), dan c. Antarwilayah di Indonesia.

1. Pola Penyebaran Investasi per Kapita Antarpropinsi di Indonesia.
Berdasarkan Tabel 3 nilai koefisien $\mathrm{T}$ dan L untuk tahun 1985 masing-masing sebesar 0,4300 dan 0,4079 dan untuk tahun 1990 nilai tersebut masing-masing sebesar 0,5568 dan 0,4597 serta untuk tahun 1995 nilai tersebut masing-masing sebesar 0,3531 dan 0,2947. Dari besaran nilai koefisien $\mathrm{T}$ dan $\mathrm{L}$ tampak bahwa pada periode tahun 1985-1990 keduanya menunjukkan tren yang semakin meningkat. Tetapi pada periode tahun 1990-1995 nilai kedua koefisien tersebut menunjukkan tren yang semakin menurun. Atau dengan perkataan lain, pola perkembangan yang berbentuk huruf $U$ terbalik, yaitu mula-mula menaik kemudian menurun selama periode pengamatan. Hal ini menunjukkan bahwa selama satu dekade (1985-1995) pola penyebaran investasi per kapita untuk kategori 
Tabel 3. Investasi Menurut Wilayah di Indonesia, Tahun 1985-1995 (persen)

\begin{tabular}{|c|c|c|c|c|c|c|c|}
\hline \multirow{2}{*}{ No. } & \multirow{2}{*}{ Wilayah } & \multicolumn{2}{|c|}{1985} & \multicolumn{2}{|c|}{1990} & \multicolumn{2}{|c|}{1995} \\
\hline & & $T$ & $\mathbf{L}$ & $\mathrm{T}$ & L & $T$ & $\mathbf{L}$ \\
\hline 1. & Antarpropinsi di Indonesia & 0,4300 & 0,4029 & 0,5560 & 0,4597 & 0,3531 & 0,2947 \\
\hline \multirow[t]{6}{*}{2.} & \multicolumn{7}{|c|}{ Antarpropinsi dalam Wilayah Pulau \& Kepulauan: } \\
\hline & a. Sumatera & 0,4413 & 0,4257 & 0,6475 & 0,4979 & 0,0896 & 0,0778 \\
\hline & b. Jawa & 0,4209 & 0,3756 & 0,4565 & 0,4146 & 0,5115 & 0,4661 \\
\hline & c. Kalimantan & 0,1884 & 0,1752 & 0,3279 & 0,3061 & 0,2993 & 0,2928 \\
\hline & d. Sulawesi & 0,0063 & 0,0061 & 0,0027 & 0,0027 & 0,0053 & 0,0053 \\
\hline & e. Indo.lainnya & 0,2533 & 0,2615 & 0,0951 & 0,0952 & 0,1793 & 0,1780 \\
\hline \multirow[t]{3}{*}{3.} & \multicolumn{7}{|l|}{ Antarpropinsi dalam Wilayah: } \\
\hline & a. Kawasan Barat & 0,4338 & 0,4067 & 0,5735 & 0,5444 & 0,3609 & 0,2720 \\
\hline & b. Kawasan Timur & 0,3715 & 0,3516 & 0,3022 & 0,2299 & 0,3319 & 0,2806 \\
\hline \multirow[t]{3}{*}{4.} & \multicolumn{7}{|c|}{ Antarpropinsi dalam Wilayah Pemilikan SDA: } \\
\hline & a. Dgn SDA-EM & 0,4926 & 0,4635 & 0,5441 & 0,4862 & 0,3127 & 0,2419 \\
\hline & b. Tnp SDA-EM & 0,3244 & 0,1610 & 0,4970 & 0,3770 & 0,4300 & 0,311 \\
\hline
\end{tabular}

Keterangan: $\mathrm{T}=$ Koefisien Entropi Theil; $\mathrm{L}=$ Koefisien Logaritmik rata-rata.

Sumber: Data BPS diolah (lihat: subbagian Data dan Sumbernya)

antarpropinsi mula-mula cenderung memusat (concentrated) kemudian berubah cenderung menyebar (spread).

2. Pola Penyebaran Investasi per Kapita Antarpropinsi dalam Wilayah di Indonesia

a. Antarpropinsi dalam Wilayah Pulau dan Kepulauan

Pada Tabel 3 berdasarkan nilai koefisien $\mathrm{T}$ dan $\mathrm{L}$, tampak bahwa untuk pulau Sumatera, Kalimantan dan Indonesia lainnya menunjukan tren mula-mula meningkat kemudian menurun (pola $\mathrm{U}$ terbalik). Sedang untuk pulau Sulawesi, kedua nilai koefisien $\mathrm{T}$ dan $\mathrm{L}$ menunjukkan tren yang mula-mula menurun kemudian meningkat (pola U). Sementara, untuk pulau Jawa kedua nilai koefisien $\mathrm{T}$ dan $\mathrm{L}$ menunjukkan tren yang semakin meningkat (pola garis yang menaik). Dari pola tersebut di atas, menunjukkan bahwa pola penyebaran investasi per kapita antarpropinsi dalam wilayah pulau Sumatera, Kalimantan dan Indonesia lainnya mula-mula memusat kemudian cenderung menjadi menyebar. Sebaliknya untuk pulau Sulawesi, pola penyebaran investasi per kapita antarpropinsi mula-mula menyebar tetapi kemudian cenderung memusat. Sedang untuk pulau Jawa, pola penyebaran investasi perkapita antarpropinsi cenderung semakin memusat.

b. Antarpropinsi dalam Wilayah Barat dan Timur Indonesia

Pada Tabel 3 berdasarkan nilai koefisien $\mathrm{T}$ dan L tampak bahwa untuk Kawasan Barat Indonesia (KBI) menunjukkan tren yang mula-mula meningkat kemudian 
menurun (pola U terbalik). Sedang untuk Kawasan Timur Indonesia (KTI) kedua nilai koefisien $\mathrm{T}$ dan $\mathrm{L}$ menunjukkan tren mula-mula menurun kemudian meningkat (pola U). Pola tren nilai koefisien $\mathrm{T}$ dan $\mathrm{L}$ seperti tersebut, menunjukkan bahwa pola penyebaran investasi per kapita antarpropinsi di KBI mulamula cenderung memusat tetapi kemudian menyebar, sedang hal yang sama untuk KTI menunjukkan hal yang sebaliknya, yaitu mula-mula menyebar tetapi kemudian cenderung memusat.

c. Antarpropinsi dalam Wilayah dengan dan tanpa Pemilikan Sumber Daya Alam- Energi Mineral (SDA-EM).

Pada Tabel 3 berdasarkan nilai koefisien $\mathrm{T}$ dan $\mathrm{L}$ tampak bahwa baik untuk Wilayah dengan Pemilikan SDA-EM maupun untuk Wilayah tanpa Pemilikan SDA-EM menunjukkan tren yang mulamula meningkat, kemudian cenderung menurun (pola $U$ terbalik). Hal ini menunjukkan bahwa pola penyebaran investasi perkapita antarpropinsi di kedua wilayah tersebut memiliki pola tren yang mula-mula memusat, kemudian berubah cenderung menyebar.

3. Pola Penyebaran Investasi Perkapita Antarwilayah di Indonesia

a. Antarpulau dan Kepulauan

Pada Tabel 3 berdasarkan nilai koefisien $\mathrm{T}$ dan L tampak bahwa untuk Pulau dan Kepulauan menunjukkan pola tren yang semakin menurun (pola garis yang menurun). Hal ini menunjukkan bahwa pola penyebaran investasi perkapita Antarpulau dan Kepulauan di Indonesia cenderung semakin menyebar. b. Antarkawasan Indonesia (Barat dan Timur)

Pada Tabel 3 berdasarkan nilai koefisien $\mathrm{T}$ dan $\mathrm{L}$ tampak bahwa untuk kawasan Indonesia (KBI dan KTI) menunjukkan tren yang mula-mula meningkat, kemudian menurun (pola U terbalik). Hal ini menunjukkan bahwa pola penyebaran investasi perkapita antar-kawasan Indonesia (KBI dan KTI) mula-mula memusat, kemudian cenderung menyebar.

c. Antarwilayah dengan dan Tanpa Pemilikan SDA-EM

Pada Tabel 3 berdasarkan nilai koefisien $\mathrm{T}$ dan $\mathrm{L}$ tampak bahwa untuk wilayah dengan dan tanpa pemilikan SDA-EM menunjukkan tren yang mula-mula meningkat kemudian menurun (pola huruf yang $U$ terbalik). Hal ini menunjukkan bahwa pola penyebaran investasi per kapita antarwilayah dengan dan tanpa SDA-EM mula-mula memusat kemudian cenderung menyebar.

\section{KESIMPULAN}

Dari beberapa hasil temuan di atas, dapat ditarik beberapa kesimpulan bahwa selama satu dekade pengamatan (tahun 1985-1995) pola penyebaran investasi per kapita di Indonesia baik antarpropinsi di Indonesia, antarpropinsi dalam wilayah di Indonesia maupun antarwilayah di Indonesia adalah sebagai berikut:

1. Penyebaran investasi perkapita antarpropinsi di Indonesia cenderung semakin menyebar dengan pola penyebaran yang berbentuk $U$ terbalik.

2. Penyebaran investasi per kapita antarpropinsi dalam Wilayah Pulau dan 
kepulauan di Indonesia menunjukkan perbedaan antarpulau dan kepulauan.

Untuk pulau-pulau Sumatera, Kalimantan dan Indonesia lainnya, penyebaran investasi per kapita cenderung menyebar dengan pola yang berbentuk $U$ terbalik. Untuk pulau Sulawesi, penyebaran investasi perkapita cenderung memusat dengan pola berbentuk U. Sedang untuk pulau Jawa, penyebaran investasi perkapita cenderung memusat dengan pola berbentuk garis yang menaik.

3. Penyebaran investasi perkapita antarpropinsi dalam wilayah kawasan Indonesia (KBI dan KTI) menunjukkan bahwa baik di KBI maupun di KTI memiliki kecenderungan yang sama, yaitu keduanya cenderung menyebar dengan pola yang berbentuk $U$ terbalik.

4. Penyebaran investasi per kapita antarpropinsi dalam wilayah dengan dan tanpa SDA-EM menunjukkan bahwa baik di wilayah dengan SDA-EM maupun di wilayah tanpa SDA-EM memiliki kecenderungan yang sama, yaitu investasi perkapita cenderung menyebar dengan pola yang berbentuk $U$ terbalik.

5. Penyebaran investasi perkapita antarwilayah baik antarpulau dan kepulauan, antarkawasan Indonesia (KBI dan KTI) maupun antarwilayah dengan dan tanpa SDA-EM menunjukkan kecenderungan yang sama yaitu cenderung semakin menyebar dengan pola yang berbentuk $U$ terbalik.

Berdasarkan beberapa temuan kecenderungan pola penyebaran investasi secara spasial seperti telah disebutkan di atas maka berikut ini beberapa catatan pokok yang perlu direnungkan antara lain:

1. Oleh karena investasi merupakan salah satu faktor utama yang menentukan proses pembangunan maka aspek pemerataan kegiatan pembangunan dan hasilnya secara spasial sangat ditentukan pula oleh pola penyebaran investasi secara spasial. Dengan perkataan lain, semakin seimbang pola penyebaran investasi secara spasial semakin cenderung merata kegiatan pembangunan dan hasilnya.

2. Selama ini di Indonesia, kebijakan pembangunan sangat didominasi oleh pembangunan secara sektoral daripada secara regional (spasial). Jadi, beberapa temuan pola penyebaran investasi yang cenderung memusat di beberapa wilayah tertentu terutama dilihat dari kategori Antar-propinsi dalam Wilayah Pulau dan kepulauan -seperti di pulau Jawa dan Pulau Sulawesi- adalah wajar sebagai konsekuensi kebijakan yang lebih berorientasi sektoral.

3. Temuan yang menarik dalam pengamatan ini adalah pola penyebaran investasi secara spasial menurut kategori Pulau dan Kepulauan. Meskipun pulau Sumatera, Kalimantan, dan pulau Indonesia lainnya menunjukkan perubahan pola penyebaran ke arah yang cenderung menyebar (spread) tetapi pulau Sulawesi menunjukkan pola yang cenderung memusat (concentrated). Bahkan pulau Jawa yang selama ini telah merupakan pusat daya tarik imvestasi yang terbesar di Indonesia baik karena kebijakan pemerintah maupun karena fasilitas infrastruktur ekonomi yang memungkinkan dibanding dengan wilayah lainnya, ternyata semakin 
menunjukkan pola penyebaran investasi yang cenderung memusat. Oleh karena itu, sudah saatnya upaya pemerataan kegiatan pembangunan dan hasilnya mulai pula dilihat dari perspektif wilayah pulau dan Kepulauan. Tidak hanya wilayah antara kawasan barat (KBI) dan timur Indonesia (KTI) seperti selama ini.

4. Dalam kerangka yang lebih luas, yaitu kerangka negara kesatuan Republik Indonesia (NKRI) secara politis, ekonomi, sosial, dan budaya, pendekatan pembangunan secara spasial merupakan faktor penunjang utama yang selama ini terabaikan.

\section{DAFTAR PUSTAKA}

Biro Pusat Statistik, (1985), Konsep dan Definisi Operasional Baku Statistik Sosial dan Kependudukan, Jakarta: BPS.

Biro Pusat Statistik, (1989), Pendapatan Regional Propinsi-propinsi di Indonesia Menurut Penggunaannya, Periode 1983-1988; Jakarta: BPS.

Biro Pusat Statistik, (1990), Pendapatan Regional Propinsi-propinsi di Indonesia
Menurut Penggunaannya, periode 19831989, Jakarta: BPS.

Biro Pusat Statistik, (1996), Pendapatan Regional Propinsi-propinsi di Indonesia Menurut Penggunaannya, Periode 1993-1995, Jakarta: BPS.

Myrdal, Gunnar, (1968), Asian Drama, Vol. 1, New York: Penguin.

Poot, Kuyvenhoven and Jansen, (1990), Industrialization and Trade in Indonesia, Yogyakarta: GadjahMada University Press.

Sarungu, J.J., (1990), Pembangunan Sosial Ekonomi, Perubahan Demografis dan Urbanisasi: Suatu Telaah Empirik di Indonesia'; Tesis (tidak dipublikasi), Jakarta, Program Pascasarjana Universitas Indonesia.

Sarungu, J.J., (2001), Pola Pengaruh Pembiayaan Pemerintah dan Swasta terhadap Proses Urbanisasi di Indonesia, 1980-1995, Disertasi (tidak dipublikasi), Surabaya, Program Pascasarjana Universitas Airlangga.

Todaro, M.P., (1977), Economic Development in the Third World, London: Longman. 